\title{
BROCA Gene Signature
}

National Cancer Institute

\section{Source}

National Cancer Institute. BROCA Gene Signature. NCI Thesaurus. Code C121989.

A prognostic system used to assess if a patient has an increased risk for developing hereditary cancer, with a focus on ovarian and breast cancers. This system is based on the use of massively parallel DNA sequencing to detect cancer predisposing mutations in a panel of more than 45 specific genes. 